\title{
Studying the Status of Marketing Mix (7Ps) in Consumer Cooperatives at Ilam Province from Members' Perspectives
}

\author{
Purashraf Yasanallah, Bidram Vahid \\ Management Department, University of Ilam, Ilam, Iran. \\ Email: yasan_ashraf@yahoo.com, vbidram@yahoo.com
}

Received July 2 $2^{\text {nd }}$, 2012; revised August $1^{\text {st }}$, 2012; accepted August 31 $1^{\text {st }}, 2012$

\begin{abstract}
Concerning the particular importance of cooperatives in a cooperation system, the author has tried to study the status of marketing mix (7Ps) in cooperatives and to provide proposals to improve the conditions of such cooperatives. This is a descriptive and survey research. Its population consists of all members of consumer cooperatives in Ilam province selected by a ranked sampling method proportionate to the volume of the population by which necessary sample was determined. According to research aim, seven hypotheses are provided and tested by one sample t-test. As a result, hypotheses on price, location, promotion, product, operation management and physical assets which show lower than average status of these elements were confirmed. The only hypothesis that was rejected was the hypothesis related to the personnel element. This shows the proper condition of this element of marketing mix.
\end{abstract}

Keywords: Cooperation; Consumer Cooperatives; Marketing; Marketing Mix

\section{Introduction}

In the past, economists believed that the important thing for growth and development of communities is physical capital. Since 1950s, another factor namely human capital and social capital was considered. According to social and economic connoisseurs, the most beautiful aspect of social capital is seen in cooperatives. Cooperatives are a new shape of economic activities which have created a new generation of middle class in the society by using the talents and facilities of majority and sharing them in the profits of their operations so they enjoy a similar ownership as a balanced combination of social-economic parameters. Often, they give their capital deliberately and voluntarily. The participation of cooperatives in social/ economic development is important since they are proper mechanism to establish social justice and to promote awareness and public culture and they move economic capitals and fertilize social capitals.

Today, we are facing with the depression of cooperatives especial consuming ones. Unsuccessful and depression of cooperatives (35\% of such cooperatives) are considered as an important challenge since depression and failure of such cooperatives waste financial resources, HR unemployment, loosing new job opportunities and a negative impact in public opinion [1]. On this basis, it is felt that cooperatives should be studied more different than before. So, a key question arises: Can discussions on marketing and implementing lead into a guideline to exit such depression?

In present study, authors attempts to look at consuming cooperatives in terms of marketing and identify the strength and weak points of cooperative and provide its recommendations to improve weak points and to enhance strength points by studying marketing mix of Ilam cooperatives including price, place, promotion, product, personnel, procedure management and physical assets.

\section{Literature Review}

Needs and demand of man is the starting point for marketing activities which pave the ground for sharing products and transaction through demand for products. Cooperatives are also established to satisfy the common needs of people. In contrary to other entities which satisfy human needs and demands through other ways, in cooperatives needs are met by members in a manner that members try to meet their own needs and demands [2]. In the time of serious problems, cooperatives can be a hopeful option [3].

The beginning of cooperatives adding movements backs to the establishment of a Rochdale's Fair Company in 1844. Cooperation refers to a collective and systematic voluntarily operation [4]. Navcovic believes that 
cooperatives are democratic organizations which create a benefit for their members [5].

Cooperatives have an important status in Iranian Constitutional Law which has led into the expansion of cooperative activities and forums and their remarkable growth [6]. According to the law, cooperatives are categorized in three ranks one of them is consumption field [7]. According to statistics provided by Cooperative Ministry, there were 155,241 registered cooperatives by Cooperative Ministry until March 2010. According to the same data, the number of cooperatives in Ilam province is more than 2000 [6].

By using marketing mix, cooperatives can further meet their members' needs and expand their sale in their nonmember markets [2].

The initial studies on marketing mix were conducted by Harvard University in 1929 [8] while the management paradigm of marketing mix was dominated the market since 1940. In 1964, McCarty developed this idea and revised them as principles recognized as 4Ps today [9]. Marketing mix includes four elements namely product, price, promotion and place [10]. Owing to the fact that any decision on each element should be compatible with other three elements, marketing mix term was selected [11]. In reality, marketing mix is a set of tools by which entities achieve their marketing goals in their target markets [12]. Booms and Bitner believe that services need another type of marketing and a different type of marketing mix. To the same reason, they distinguished service marketing from product marketing. In their marketing mix, three Ps namely personnel, physical assets and procedures were added and finally 7Ps were shaped [13].

Below, one can find the definition of marketing mix elements:

Product is all necessary components and elements to do a service which generate value for customer [14]. Product is an element of marketing mix which respecting it in cooperatives leads into the satisfaction of members and customers. For instance, supplying products with a credible brand and attractive package increase the sale in addition to the satisfaction of customers [2].

Price and other costs of service sector show the management of various costs endured by customers in achieving the advantages from generating the services [14]. In consumer cooperatives, the first and main aim is to satisfy members that should be considered in pricing followed by achieving the profit, sale increase, more share in the market, survival and development of the company [2].

Place is the managerial decisions on where customers should be provided with services and it may include electronic/physical distribution channels [14]. Consumer cooperatives are a kind of distribution channels which can establish the relationship between consumers and manufacturers and play a vital role in mitigating the prices and preventing the growth of unnecessary dealers [2].

The value and importance of promotion for service organization is in the benefits achieved from buying their services. In many cases, promotional methods are similar for services and products [14]. In the position of economic corporation, consumer cooperatives have the function to distribute products among members and other consumers and it is necessary that they move toward promotional activities to increase their sale.

Personnel are a main component in providing services [15]. According to Pheng and Martin, personnel are the only component that provides customers with services. Since consumer cooperatives are firms in which employees face with consumers directly, such organizations try to achieve a special situation in the market through training their employees on sale knowledge and how to treat with customers [16].

Procedure management ensures availability and sustainable/proper quality of services. The task and role of this component of marketing mix is to balance service demand and supply [17]. By improving the procedure of providing services to customers, cooperatives can pave the ground for consumers' convenience which leads into repurchase and, finally, sale increase.

Physical assets refer to environment and facilities needed by companies to provide services to their customers [18]. Consumer cooperatives can expand consumers' choices by providing facilities like self-service, paramount shelves, etc as same as big shops and can prevent that a buyer leaves the company without any purchase.

In their study, Safari, Aryanfar and Ebrahimi studied structural, contextual and content factors and their impact on the success of consuming cooperatives. Marketing shapes a content factor as one of the most important elements in the success of consuming cooperatives. It seems that the authors have not been able to study all elements due to the quantity of structural, contextual and content factors. Therefore, it seems necessary to study each factor separately especially marketing factor in the success of cooperatives [19].

Zaranejad and Sharifi say that workforce mixed with what called as employees can impact on productivity. In present research, constituents like training, consultancy and education are used to study the impact of manpower on the productivity of cooperatives. Therefore, studying the status of marketing mix with more constituents can remarkably help to improve their productivity [20]. Ebrahimi, Toluei, Mahdieh and Kanani found some reasons for the stagnation of cooperatives and they explored 
it in members' contribution which in present study, the author also looks for it. The results of this research could show the necessity of more attention to the components of marketing mix [21].

Davies and Burt (2007) studied the internationalization of retail cooperatives. They attempted to expand the reasons of cooperatives' failure generally and to prepare more profound literature on internationalization of cooperatives but they forgot to consider the application of marketing in cooperatives' internationalization [22].

Considering new economic conditions of the country on the objectivity of subsidies and owing to the fact that removing the problems of consumer cooperatives impacts on purchase increase and the level of members' lives directly, the author decided to measure the status of marketing mix in consumer cooperatives at Ilam province and to provide guidelines to enhance marketing mix in order to improve the performance of such cooperatives and to meet members' satisfaction.

The aim of present research is to study the status of marketing mix (7Ps) in consumer cooperatives at Ilam province. To this end, seven hypotheses are devised:

1) The status of price in consumer cooperatives is lower than average;

2) The status of place in consumer cooperatives is lower than average;

3 ) The status of promotion in consumer cooperatives is lower than average;

4) The status of product in consumer cooperatives is lower than average;

5) The status of personnel in consumer cooperatives is lower than average;

6) The status of procedure management in consumer cooperatives is lower than average;

7) The status of physical assets in consumer cooperatives is lower than average.

\section{Methodology}

Present study is a quantitative and applied one and it is a descriptive-survey in terms of research type. To collect information on research background and theoretical framework, library method and to collect needed information on testing the hypotheses and measuring members' opinions, feasibility study method along with a questionnaire is used. The validity of the questionnaire is confirmed by connoisseurs and its reliability is also supported by using Cronbach's alpha (0.814).

Its population consists of all members $(11,495)$ of consumer cooperatives in Ilam province selected by a ranked sampling method (193 subjects) proportionate to the volume of the population by which necessary sample was determined. Table 1 indicates the share of each rank based on the type of the consumer cooperative.
Table 1. The share of each rank at population for sampling.

\begin{tabular}{|c|c|c|c|c|}
\hline $\begin{array}{c}\text { Employer- } \\
\text { Based }\end{array}$ & Local & Cultural & $\begin{array}{l}\text { Labor- } \\
\text { Based }\end{array}$ & $\begin{array}{c}\text { Cooperative } \\
\text { Members }\end{array}$ \\
\hline 4986 & 267 & 5205 & 1037 & Members \\
\hline 0.432 & 0.023 & 0.452 & 0.09 & Shares \\
\hline
\end{tabular}

Source: Comprehensive system of registered statistics by Cooperative Ministry 2011 and authors' calculations.

Finally, the questionnaires were distributed more than determined quantity and 199 ones were returned. The questionnaire consists of general and special items based on previous questionnaires, conducted studies and the opinions of guiding professors/advisors. General questions consist of members' demographical traits including gender, age, education and two questions based on a face scale. The special questions gathered their ideas about marketing mix based on Likert five-scale. The constituents of research hypotheses are shown in Table 2.

By using one sample t-test in SPSS, research hypotheses were tested so that numbers were initially hypothesized for population average and then through t-test is was determined whether they are true or false. Freedman test was used to rank marketing mix components.

\section{Discussion and Conclusion}

Of 199 distributed questionnaires, 164 belonged to men and 35 to women. In terms of gender, most consumers and members of cooperatives (82\%) are men. It shows limited membership of women in the cooperatives. Since women constitute a main part of shoppers throughout the world, it is necessary that cooperative step toward more participation of women in such cooperatives through implementing special marketing plans.

The answers of respondents to their age are outlined in Table 3.

As seen in Table 3, more than $50 \%$ of members are less than 40. It shows that they can be de facto customers of cooperative in at least next 20 years and cooperatives should use encouraging activities to maintain this major resource.

Table 4 shows that more than $50 \%$ of members' cooperatives have M. A. and higher education. According to such level of education, this should be included in propagandas and other marketing activities by cooperatives.

The first hypothesis studies the status of price in the consumer cooperatives. By using one sample t-test, this hypothesis is converted into statistical hypotheses namely $H_{1}$ (the claim) and $H_{0}$ (the contrary).

$H_{0}$ : The status of price in consumer cooperatives is equal or higher than average;

$\mathrm{H}_{1}$ : The status of price in consumer cooperatives is lower 
Table 2. The constituents of each hypothesis variable.

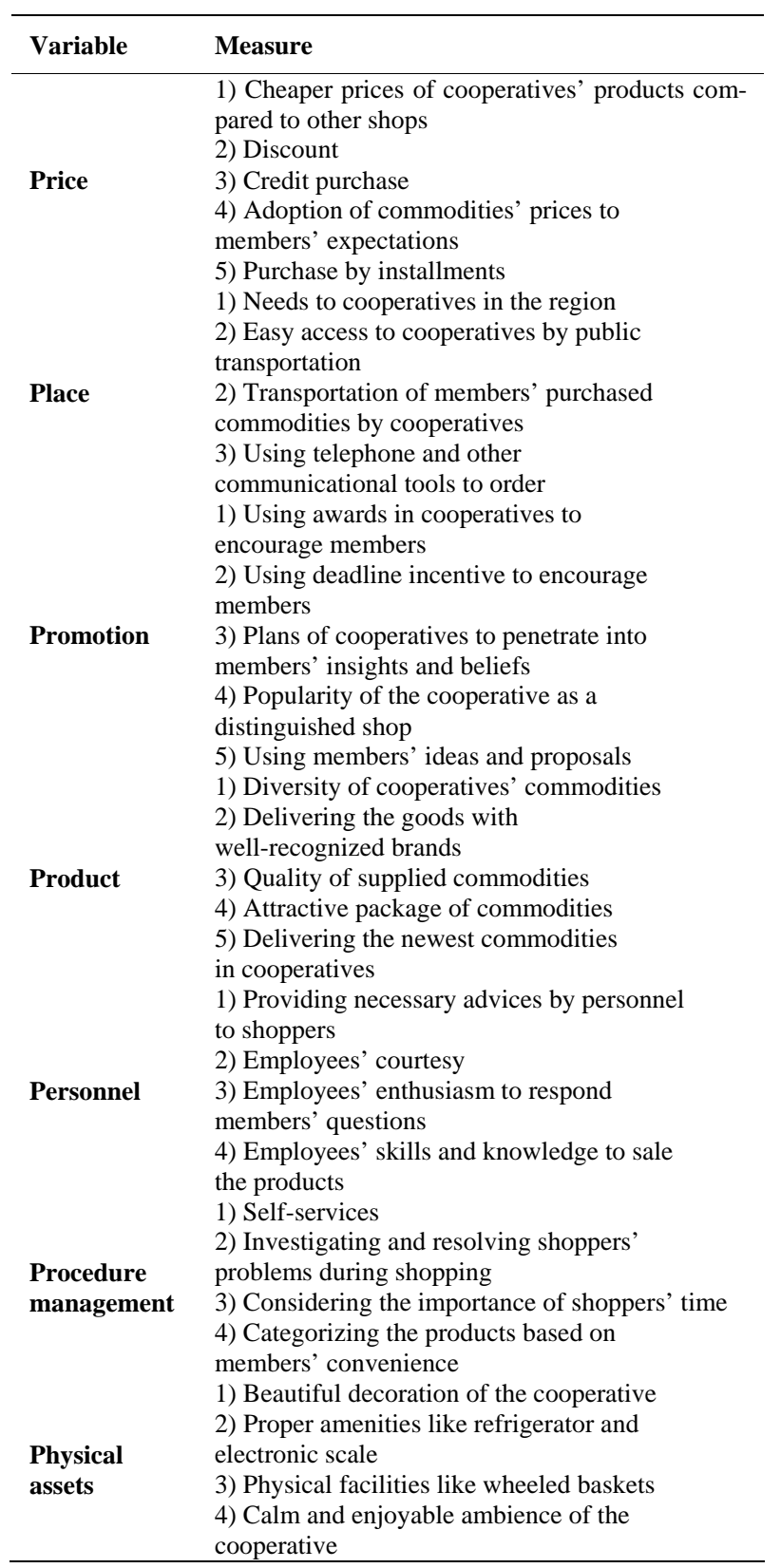

Table 3. The frequency of respondents' age.

\begin{tabular}{ccc}
\hline Frequency (\%) & Frequency & Age \\
\hline 17.6 & 35 & $<30$ \\
48.2 & 96 & $31-40$ \\
28.6 & 57 & $41-50$ \\
3 & 6 & $51-60$ \\
1 & 2 & $<61$ \\
98.5 & 196 & Total \\
1.5 & 3 & NA \\
100 & 199 & Total \\
\hline
\end{tabular}

Source: Author's calculations.
Table 4. The frequency distribution of respondents' educational level.

\begin{tabular}{ccc}
\hline$\%$ & Frequency & Education \\
\hline 4 & 8 & Under Diploma \\
16.6 & 33 & Diploma \\
22.6 & 45 & Associate of art \\
47.2 & 94 & Bachelor \\
8.5 & 17 & Masters and higher \\
99 & 197 & Total \\
1 & 2 & NA \\
100 & 199 & Total \\
\hline
\end{tabular}

Source: Author's calculations.

than average.

$$
\begin{aligned}
& H_{0}: \mu_{x} \geq 3 \\
& H_{1}: \mu_{x}<3
\end{aligned}
$$

Other hypotheses are explained as above and their results are shown in Table 5.

Table 5 shows that the average of respondents' opinions on the status of price, place, promotion, product, physical asset and procedure management in cooperatives is lower than 3 and less than test rate. Concerning the estimated significance level (0.000) and in $0.95 \%$ as confidence level, one can claim that the status of such components in consumer cooperatives is lower than average. On the other hand, concerning the one-way test and negative high and low levels, the average rate of all six variables is smaller. Therefore, $H_{0}$ is rejected. In fact, since the critical figure in the table is 1.64 and calculated $\mathrm{t}$ is less than mentioned $\mathrm{t}$ in the table, $H_{0}$ is rejected and the contrary hypotheses are supported, that is, $H_{1}$ is supported for six hypotheses and it is only rejected for hypothesis 5 (personnel) which shows better situation of this component than other ones.

\section{Ranking Hypotheses' Variables}

Friedman test is used to rank the variables of hypotheses in order to identify which component in marketing mix has better situation than other components. The results are shown in Table 6. As seen in the table, personnel component has the best and promotion has the worst status. Bad situation of promotion shows the lack of attention by cooperatives' officials to this valuable component. Lovelock and Wright (2003) equals watching to sale. This shows the importance of all marketing mix components including incentives and awards. After promotion, price has the worst status. This also shows the 
Table 5. The results of testing hypotheses.

\begin{tabular}{cccccccc}
\hline Low level & High level & Standard deviation & average & Significance level & T & df & variable \\
\hline-0.9508 & -0.7437 & 0.740 & 2.152 & 0.000 & -16.132 & 198 & Hypothesis 1 \\
-0.8810 & -0.6626 & 0.781 & 2.228 & 0.000 & -13.935 & 198 & Hypothesis 2 \\
-1.1209 & -0.9002 & 0.789 & 1.989 & 0.000 & -18.067 & 198 & Hypothesis 3 \\
-0.4423 & -0.2039 & 0.825 & 2.676 & 0.000 & -5.347 & 198 & Hypothesis 4 \\
-0.0044 & 0.2356 & 0.858 & 3.115 & 0.059 & 1.899 & 198 & Hypothesis 5 \\
-0.7191 & -0.5020 & 0.776 & 2.389 & 0.000 & -11.091 & 198 & Hypothesis 6 \\
-0.3930 & -0.1371 & 0.915 & 2.734 & 0.000 & -4.086 & 198 & Hypothesis 7 \\
\hline
\end{tabular}

Source: Author's calculations.

Table 6. Ranking the variables of hypotheses.

\begin{tabular}{ccc}
\hline Rank & Rank average & Variable \\
\hline 6 & 3.03 & Price \\
5 & 3.33 & Place \\
7 & 2.50 & Promotion \\
3 & 4.61 & Product \\
1 & 5.90 & Personnel \\
4 & 3.81 & Procedure management \\
2 & 4.82 & Physical assets \\
\hline
\end{tabular}

Source: Author's calculations.

lack of attention by officials.

\section{Conclusion and Recommendation}

Of seven mentioned hypotheses, 6 ones were confirmed and the hypothesis on the status of personnel was refused. It shows the low position of marketing mix 7Ps in Ilam consumer cooperatives. Friedman test indicated that among marketing mix components, Personnel have the best and promotion has the worst status.

\subsection{Suggestion for Managers at Ilam Consumer Cooperatives}

In developed countries, there are huge costs on advertising and it has a close relationship with their economic progress. Concerning the average of marketing mix components and low average of promotion compared to other variables, cooperatives' managers are recommended do not fear the costs of advertising and step toward it. They should remind members to purchase cooperatives by providing with incentives.

Complaining customers, in fact, are providing the company with the opportunity to reform problems, to revise their relations with complainants and to remedy the quality of their services. On this basis, cooperatives' managers are recommended to patient in resolving the problems of members and shoppers and address to members' recommendations and critics by organizing regular meetings.

Although personnel component has the best status among other marketing mix components, cooperatives' managers are recommended to address their employees and increase their awareness and train them in order to improve this status since customers know service providers under the name of the organization and if the personnel have not passed adequate training, it will be difficult for them to provide competent services.

The key of effective pricing is to recognize shoppers' traits, the reason of their shopping and how to decide to shop. Since many members of cooperatives are employees of entities with medium income level, discounts can impact highly on the purchase by such members. Hence, cooperatives' managers are recommended to decrease the prices rationally or to give discounts to shoppers and to pave the ground for paying the price of expensive commodities by installments so that customers and members will be encouraged to further shopping.

Customers look for more convenience and they expect to receive their goods anywhere and anytime they like. On this basis, cooperatives' managers are recommended to establish phone order and delivery system in order to pave the ground for more orders and eliminate shoppers' concerns by transporting heavy and big commodities.

Cooperatives' managers are recommended to establish a regular polling system in order to identify customers' demands and to meet them. In the meantime, by providing a variety of products like home appliances, clothes, cosmetics, etc, they can pave the ground that customers can find all their needed goods through one cooperative.

The conditions of physical ambience can impact negatively or positively and most companies pay high atten- 
tion to this issue. Unfortunately, it is neglected in most cooperatives at Ilam. The appearance of the environment aids to proper feeling and reflection of customers and personnel. On this basis, cooperatives' managers are recommended to create conditions for buyers to purchase in an enjoyable sense by designing a nice, clean and healthy physical ambience.

Since shoppers tend to buy commodities with broad propaganda or in other words, to buy modern goods, cooperatives' managers are recommended to supply such goods. Shoppers prefer to find commodities in different brands when they enter cooperatives.

\subsection{Suggestion for Future Study}

Future researchers are recommended to study the status of marketing mix in consumer cooperatives in next year's and compare their findings with this research and then investigate about the reasons of improving or worsening the situation.

Since the author has simply studied the status of marketing mix in members' perspective, future authors are recommended to study the status of marketing mix in other cooperatives including manufacturing ones.

According to findings of promotion component with the worst status among other elements of marketing mix, future authors are recommended to study this element separately.

Since the author has simply studied the status of marketing mix in members' perspective, future authors are recommended to study it in managers' perspective and compare the ideas of both groups.

\section{Research Limitations}

The lack of precise and updated information on consuming cooperatives in Ilam Cooperative Directorate made it difficult for author to access such cooperatives.

Since Ilam is a border province, it has special political and geographical status which makes it difficult to conduct such researches and to gather needed data.

\section{REFERENCES}

[1] A. Samadi, "Studying the Dynamism or Stagnation of Manufacturing Cooperatives in Hamedan,” A Research Proposal by Hamedan Cooperative Directorate, 2000.

[2] M. H. Mostaani, "The Management of Consumer Cooperatives,” Paygan Publications, Tehran, 2005.

[3] K. Mikami, "Capital Procurement of a Consumer Cooperative: Role of the Membership Market,” Economic Systems, Vol. 34, No. 2, 2010, pp. 178-197. doi:10.1016/j.ecosys.2009.09.004

[4] M. Abbassi, "Cooperative Belief, Iran Rural Develop- ment Publications,” Tehran, 2010.

[5] S. Navcovic, "Defining the Coperative Difference," The Journal of Socio-Economics, Vol. 37, No. 6, 2008, pp. 2168-2177. doi:10.1016/j.socec.2008.02.009

[6] Cooperative Ministry, "Statistics and Profiles of Employed and Unemployed Population,” Office of Statistics and Information Technology, Tehran, 2010.

[7] Cooperative Ministry, "Business in Cooperatives," Sabzan Publications, Tehran, 2007.

[8] M. Baker, "Marketing Strategy and Management,” McMillan, London, 2000.

[9] L. G. Chai, “A Review of Marketing Mix: 4Ps or More?” International Journal of Marketing Studies, Vol. 1. No. 1, 2009, pp. 2-15.

[10] D. Jobber, "Principles \& Practice of Marketing," 3rd Edition, McGraw-Hill, England, 2001.

[11] J. Mullins, O. Walker and H. Boyd, "Marketing Management,” 6th Edition, McGraw-Hill, New York, 2008.

[12] H. Alvedari, "Marketing and Market Management," Payam Noor University, Tehran, 2005.

[13] M. Rafiq and P. K. Ahmed, "Using the 7Ps as a Generic Marketing Mix: an Exploratory Survey of UK and European Marketing Academics,” Marketing Intelligence \& Planning, Vol. 13, No. 9, 1995, pp. 4-15. doi:10.1108/02634509510097793

[14] C. Lovelock and L. Wright, "Marketing Principles and Services,” SAMT Publications, Tehran, 2003.

[15] P. Dargi, "Service Marketing Through Iranian Market Perspective,” Rasa Publications, Tehran, 2009.

[16] L. S. Pheng and M. Tan, “A Convergence of Western Marketing Mix Concepts and Oriental Strategic Thinking," Marketing Intelligence \& Planning, Vol. 13, No .2, 1995, pp. 11-36.

[17] A. Rusta, D. Venus and A. Ebrahimi, "Marketing Management,” SAMT Publications, Tehran, 2005.

[18] R. E. Goldsmith, “The Personalized Marketplace: Beyond the 4Ps,” Marketing Intelligence \& Planning, Vol. 14, No. 4, 1999, pp. 178-185. doi:10.1108/02634509910275917

[19] H. Safari, K. Aryanfar and A. Ebrahimi, "Affecting Factors on the Success of Superior Consumer Cooperatives," Taavon, Vol. 212, No. 20, 2009, pp. 33-51.

[20] M. Zaranejad and B. Sharifi, "Studying the Attitudes of Members and Managers of Consumer Cooperatives on Affecting Factors on Productivity Improvement," Liberal Arts and Social Science Research Letter, Vol. 29, No. 8, 2008, pp. 97-118.

[21] A. Ebrahimi, A. Taati, O. Mahdieh and A. Kanaani, “Affecting Factors on Promoting Members' Contribution in Unions and Consumer Cooperatives,” Taavon, Vol. 2, No. 21, 2010, pp. 129-153.

[22] K. Davies and S. Burt, "Consumer Cooperatives and Retail Internationalization: Problems and Prospects," International Journal of Retail \& Distribution Management, Vol. 35, No. 2, 2007, pp. 156-177. 